\title{
What can we learn about wildlife killed by vehicles from a citizen science project? A comparison of scientific and amateur tropical roadkill records
}

\author{
Julián Monge-Nájera \\ Laboratorio de Ecología Urbana, Universidad Estatal a Distancia (UNED), 2050 San José, Costa Rica, julianmonge@gmail.com
}

Received 22-XI-2017 • Corrected 23-XI-2017 • Accepted 12-XII-2017

\begin{abstract}
In 1995, Costa Rica had one of the first citizen science projects on roadkills, which identified the most frequent species and their rates by road length, and currently it has one of the largest iNaturalist projects on the same subject. Here I assess what information can be extracted from this type of project and how results compare with those from professionals. I analyzed over 900 records from Fauna Silvestre en Carreteras de Costa Rica, from October 2013 through August 2017. There was no sexual difference in participation or productivity, but per capita output was 12 times higher than in the Brazilian CBEE project. Some species suffered higher mortality during reproduction, while the anteater T. mexicana suffered more in the dry season, when food was scarce. Roadkills matched seasonal changes in traffic routes and the geographic distribution of records in relation to urban areas reflected the ecology of each species. At least for this case, citizen science can provide reliable data about species frequency in roadkills, and data were detailed enough to identify seasonal and geographic differences at the species level for the mammals and reptiles that made up the majority of records.
\end{abstract}

Key words: roadkill, road mortality, iNaturalist, citizen science.
RESUMEN: ¿Qué podemos aprender de un proyecto de ciencia ciudadana sobre la mortalidad de vida silvestre por vehículos? Una comparación de registros de científicos y aficionados sobre muertes en carreteras tropicales. En 1995, Costa Rica tuvo uno de los primeros proyectos de ciencia ciudadana sobre muerte en carreteras, que identificaba las especies más frecuentes y sus tasas por longitud de camino, y actualmente tiene uno de los proyectos de iNaturalist más grande sobre el mismo tema. Aquí evalúo qué información se puede extraer de este tipo de proyectos y cómo se comparan los resultados con los de los profesionales. Analicé más de 900 registros de Fauna Silvestre en Carreteras de Costa Rica, de octubre de 2013 a agosto de 2017. No hubo diferencia sexual en participación o productividad, pero el producto per cápita fue 12 veces mayor que en el proyecto brasileño CBEE. Algunas especies sufrieron una mayor mortalidad durante la época de reproducción, mientras que el oso hormiguero T. mexicana sufrió más en la estación seca, cuando la comida era escasa. La muerte en carreteras coincidió con los cambios estacionales en las rutas de tráfico y la distribución geográfica de los registros en relación con las áreas urbanas refleja la ecología de cada especie. Al menos para este caso, la ciencia ciudadana puede proporcionar datos confiables sobre la frecuencia de las especies atropelladas en carretera, y los datos fueron lo suficientemente detallados para identificar las diferencias estacionales y geográficas a nivel de especie para los mamíferos y reptiles que constituían la mayoría de los registros.

Palabras clave: mortalidad en carretera, atropellos en carretera, iNaturalist, ciencia ciudadana.
Citizen science has experimented a boom in the last ten years, and millions of volunteers donate billions of dollars in work hours (Theobald et al., 2015). One field in which citizen science is very active is recording wildlife deaths in roads, and a study in Canada found that the data provided by volunteers are reliable enough to correctly identify road sections that need mitigation measures (Paul et al., 2014; Chandler et al., 2017), but there are no equivalent comparisons from tropical ecosystems.
The practical uses and effects on conservation of amateur data vary greatly, but it has been estimated that two thirds of citizen science projects lack verifiable, standardized and freely accessible data; perhaps even worse, most of them are never used for peer-reviewed research (Theobald et al., 2015). The waste of such data is particularly regrettable in tropical countries, where biodiversity is more endangered and resources for its study and conservation are scarcer (Vincent et al., 2014). 
Costa Rica, one of the leaders in tropical biodiversity conservation, had one of the first citizen data projects about roadkills, which two decades ago estimated death rates by distance (Monge-Nájera, 1996). It also found that dogs and cats were the main victims by total counts, and that the most frequent wildlife victims were Didelphis marsupialis and Tamandua mexicana (MongeNájera, 1996). After a 15-year hiatus, Costa Rican roadkill research revived in a variety of studies about which species were more affected, mortality rates and remediation options (e.g. Rojas, 2011; Araya-Gamboa \& Salom-Pérez, 2013; Arévalo et al., 2017).

Recently, Gutiérrez (2017) analyzed the first year and a half of the online public project Fauna Silvestre en Carreteras de Costa Rica, one of the largest in iNaturalist. He found that most volunteers failed to produce reports, and that sometimes photographs lacked indication of scale and basic taxonomic characters. Like Theobald et al. (2015), he lamented that data from many projects were not used for scientific research (Gutiérrez, 2017).

Here I analyze data from that project when it has been online for over three years; compare its current status with the findings of Gutiérrez (2017), and assess what information can be extracted from this type of project and how results compare with those from professionals.

\section{METHODS}

I analyzed over 900 records published by Rodolfo Artavia's Fauna Silvestre en Carreteras de Costa Rica, a citizen science project established in 2013 to record animals killed by vehicles in Costa Rican roads and highways (https://www.inaturalist.org/projects/faunasilvestre-en-carreteras-de-costa-rica). Data cover the period 31 October 2013 to 30 August 2017. I imported the dataset to Excel; and applied statistical tests with free online software from vassarstats.net and calculator.net. Additionally, maps were produced with ArcGIS.

Ethics: Public, citizen science data are analyzed for scientific, non-commercial purposes, giving proper citation of source, according to the Creative Commons License of the site iNaturalist from which they were taken (https:// www.inaturalist.org/pages/network; and https://www. inaturalist.org/pages/how+can+i+use+it). The author declares no conflict of interest.

\section{RESULTS}

There was no difference in the number of records and species published by female and male collaborators (Mann-Whitney UTests, $p=0,37$ for records and $p=0,37$ for species). For the whole period studied, each collaborator submitted a mean of 23 records (Standard Deviation 58,8 ; range $1-320, \mathrm{~N}=41$ ) and identified a mean of five species (Standard Deviation 7,7; range 0-38, $\mathrm{N}=41$ ).

The database reports that the species with most total records are Tamandua mexicana (73 observations), Didelphis marsupialis (66 observations), Procyon lotor (42 observations) and Rhinella marina (39 observations). The highest monthly averages correspond to Didelphis marsupialis, Tamandua mexicana and Rhinella marina (Digital Fig. 1).

Dry and wet season data cannot be compared "raw" because there are less dry months and wet months in Costa Rica. If the total number of records is divided by the number of rainy and dry months, three species have slightly higher ratios in the rainy season: Nasua narica $(1,7$ records per rainy months versus 1 record per dry month), Didelphis marsupialis $(2,90$ versus 2,58$)$ and Procyon lotor $(2,14$ versus 1,57$)$. Tamandua mexicana shows the opposite trend $(2,21$ versus 2,45$)$; and Rhinella marina had a much higher mean number of records in the rainy season (14 versus 1,67$)$.

The overall records also differ geographically between seasons. During the rainy season there is a higher number of records along the Pacific coastal road, while in the dry season, when the highland Talamanca road is safer for drivers, there is an increase in the number of deaths recorded along that road (Digital Fig. 2). In the northeast region of Guanacaste, there seems to be a concentration of records near water courses during the dry season (Digital Fig. 2).

\section{Individual analyses for species with most records}

The opposum, Didelphis marsupialis, was recorded more often as victim of road accidents near urbanized areas, particularly near rivers during the dry season in the Guanacaste area (Digital Fig. 3).

The other common species were recorded more often away from urban areas, with no clear seasonal differences (Digital Fig. 4, 5, 6, 7). 
Records of the frog, Rhinella marina, however, show particular patterns; they concentrate at the interface between agricultural land and forest, and are rare in highlands and in the dry season (Digital Fig. 6 and 8).

\section{DISCUSSION}

To my knowledge, no previous studies compared the participation and output of volunteers according to gender, so this study can become the basis for future research on the topic. An indirect mention can be made to Lewandowski et al. (2017), who reported that men can feel more confident, but less inclined, to produce citizen science data. My results, though, indicate no sexual difference in participation or productivity.

The ratio of 23 records per volunteer in my results is three times higher than when the project was "younger", and 12 times higher than the output of the larger but similar Brazilian CBEE project (Gutiérrez, 2017).

The same four vertebrates (T. mexicana, D. marsupialis, P. lotor and R. marina) have been reported as abundant in scientific studies of Costa Rican roadkill victims (Artavia et al., 2015), i.e. this result may be interpreted as favorable to the idea that citizen science can provide reliable data, at least for the question of which species occur commonly in roadkills. Additionally, these results resemble those from the only other citizen science study available (Monge-Nájera, 1996). However, comparisons must be careful because most studies only refer to limited parts of the country, which have their own fauna (Artavia et al., 2015; Gutiérrez, 2017).

The slightly higher mortality that appears to take place in the rainy season may reflect increased displacements for reproduction (Valenzuela \& Ceballos, 2000; Artavia et al., 2015). The anteater T. mexicana also dies in higher numbers during the dry season in Colombian roads (Nadjar \& De la Ossa, 2013). A potential reason is that ants are scarcer in dry habitats (Janzen \& Schoener, 1968), and maybe more anteaters die in the dry season because they need to travel more to find enough food. However, the seasonal behavior of T. mexicana is quite poorly known and only further study can answer this question reliably.

The finding that roadkills match a seasonal change in traffic routes is expected because, as a rule, where there are more vehicles there are more roadkills (Eloff \& Van Niekerk, 2008). Like other rules, though, this one has exceptions and it is best to analyze species individually (Monge-Nájera, 2018).
The specific geographic distribution of records also matches the known ecology of animals, i.e. those associated with human dwellings, like D. marsupialis, are frequently killed near urbanized areas, and vice versa (e.g. Tamandua mexicana).

In conclusion, in this project output was very good, women were as productive as men, "top species" results matched work done by scientists and were detailed enough to identify seasonal and geographic differences at the species level for the mammals and reptiles that made up the majority of records.

\section{ACKNOWLEDGMENTS}

I thank Zaidett Barrientos Llosa for her support and ideas, Maribel Zúñiga for the graph and maps, and Carolina Seas for her assistance with the manuscript.

\section{REFERENCES}

Alfaro, V. C., \& Quesada, F. D. (2013). Atropello de mamíferos silvestres en la ruta de acceso al cantón de Liberia, Guanacaste, Costa Rica. Revista Ventana, 7(1), 12-14.

Araya-Gamboa, D., \& Salom-Pérez, R. (2013). Informe: Identificación de pasos de fauna y medidas de mitigación sobre el camino de la Ruta 415 dentro del Subcorredor Biológico "Paso del Jaguar". Costa Rica: Panthera. Mimeografiado.

Arévalo, E., Arce, A., \& Honda, W. (2012). Mortalidad de vertebrados en el límite sur oeste del Parque Nacional Carara, Costa Rica. Revista Mesoamericana, 12(2), 103.

Arévalo, J. E., Honda, W., Arce-Arias, A., \& Häger, A. (2017). Spatio-temporal variation of roadkills show mass mortality events for amphibians in a highly trafficked road adjacent to a national park, Costa Rica. Revista de Biología Tropical, 65(4), 1261-1276.

Artavia, R. A. (2015). Identificación y caracterización de cruces de fauna silvestre en la sección de la ampliación de la carretera nacional Ruta 32, Limón, Costa Rica. Tesis de maestría. CATIE, Turrialba, Costa Rica.

Artavia, A., Jiménez, M., Martínez-Salinas, A., Pomareda, E., Araya-Gamboa, D., \& Arévalo-Huezo, E. Registro de mamíferos silvestres en la sección de la ampliación de la Ruta 32, Limón, Costa Rica. Brenesia, 83-84, 37-46.

Chandler, M., See, L., Copas, K., Bonde, A. M., López, B. C., Danielsen, F., ... \& Rosemartin, A. (2017). Contribution of citizen science towards international biodiversity monitoring. Biological Conservation, 213, 280-294.

Eloff, P., \& Van Niekerk, A. (2008). Temporal patterns of animal-related traffic accidents in the Eastern Cape, South 
Africa. South African Journal of Wildlife Research, 38(2), 153-162.

Gutiérrez, S. D. R. (2017). Evaluación del riesgo de las carreteras nacionales para la fauna silvestre y el uso de ciencia ciudadana como herramienta para el monitoreo de fauna silvestre atropellada en Costa Rica. Tesis de maestría. Universidad Nacional, Heredia, Costa Rica.

Janzen, D. H., \& Schoener, T. W. (1968). Differences in insect abundance and diversity between wetter and drier sites during a tropical dry season. Ecology, 49(1), 96-110.

Lewandowski, E., Caldwell, W., Elmquist, D., \& Oberhauser, K. (2017). Public Perceptions of Citizen Science. Citizen Science: Theory and Practice, 2(1), 3

Monge-Nájera, J. (1996). Vertebrate mortality in tropical highways: The Costa Rican case. Vida Silvestre Neotropical, 5(2), 154-156.

Monge-Nájera, J. (2018). Road kills in tropical ecosystems: a review with recommendations for new research and mitigation. Revista de Biología Tropical, 66, in press.

Nadjar, O. D. O., \& De la Ossa, J. (2013). Fauna silvestre atropellada en dos vías principales que rodean los Montes de María, Sucre, Colombia. Revista Colombiana de Ciencia Animal-RECIA, 5(1), 158-164.

Paul, K., Quinn, M. S., Huijser, M. P., Graham, J., \& Broberg, L. (2014). An evaluation of a citizen science data collection program for recording wildlife observations along a highway. Journal of environmental management, 139, 180-187.

Paul, K., Quinn, M. S., Huijser, M. P., Graham, J., \& Broberg, L. (2014). An evaluation of a citizen science data collection program for recording wildlife observations along a highway. Journal of environmental management, 139, 180-187.
Pomareda, E. (2012). Atropello de fauna Silvestre y su rescate en Cañas, Guanacaste. Presentación en Foro: "Marco Legal para la Regulación del Impacto de Infraestructura Vial y Eléctrica en la Vida Silvestre en Costa Rica". UNED. San José, Costa Rica.

Rojas-Chacón, E. (2011). Atropello de vertebrados en una carretera secundaria en Costa Rica. Vertebrate road-kills in a secondary road in Costa Rica. UNED Research Journal, $3(1), 81-84$.

Sáenz, J., Langen, T., \& Torres, L. (2012) Mortalidad de fauna silvestre por atropellamiento en la carretera interamericana que cruza el Área de Conservación Guanacaste y Determinación de pasos de fauna. Presentación en Foro: "Marco Legal para la Regulación del Impacto de Infraestructura Vial y Eléctrica en la Vida Silvestre en Costa Rica". UNED. San José, Costa Rica.

Theobald, E. J., Ettinger, A. K., Burgess, H. K., DeBey, L. B., Schmidt, N. R., Froehlich, H. E., ... \& Parrish, J. K. (2015) Global change and local solutions: Tapping the unrealized potential of citizen science for biodiversity research. Biological Conservation, 181, 236-244.

Torres T., M.L. (2011). Funcionalidad de estructuras subterráneas como pasos de fauna en la carretera interamericana norte que cruza el área de conservación Guanacaste, Costa Rica. Tesis de maestría. CATIE, Turrialba, Costa Rica.

Valenzuela, D., \& Ceballos, G. (2000). Habitat selection, home range, and activity of the white-nosed coati (Nasua narica) in a Mexican tropical dry forest. Journal of mammalogy, 81(3), 810-819.

Vincent, J. R., Carson, R. T., DeShazo, J. R., Schwabe, K. A., Ahmad, I., Chong, S. K., ... \& Potts, M. D. (2014). Tropical countries may be willing to pay more to protect their forests. Proceedings of the National Academy of Sciences, 111(28), 10113-10118.

\section{EDITED BY CAROLINA SEAS}

See Digital Appendix at: / Ver Apéndice digital en: http://investiga.uned.ac.cr/revistas/index.php/cuadernos 